\title{
Penilaian Konsumen Millennial terhadap Tingkat Usabilitas Produk Smartphone
}

\author{
Devy Dwi Orshella ${ }^{1}$, Widodo Andri Saputro ${ }^{2}$ \\ 1,2 Teknik Industri Universitas Galuh \\ Jln. R.E. Martadinata No. 150, Kab. Ciamis, Jawa Barat \\ 11devorshella@gmail.com
}

Dikirimkan: 09, 2018. Diterima: 09, 2018. Dipublikasikan: 10, 2018.

\begin{abstract}
The development of smartphone technology in Indonesia is certainly inseparable from the influence of the millennial lifestyle. Millennial generation are the most socially connected generation and has dominated the number of smartphone users in Indonesia in the last three years. One of the technological developments is smartphone interface. Good interface usability will make it easier for users, and increase loyalty to the product. So that this research was conducted to find out the comparison of the usability level of the interface of the two best-selling smartphone products in Indonesia, namely the Iphone and Samsung. The study was carried out by direct observation of respondents who represented the millennial generation in Ciamis Regency. Respondents will complete 10 tasks in four trials on each smartphone interface. The results of this study indicate that the Samsung interface is superior to the dimensions of efficiency, error, and memorability. While the Iphone interface is superior to the dimensions of learnability and satisfaction. In addition, there are also recommendations for improvement proposals that can be made by developers to improve the smartphone product interface.
\end{abstract}

Keywords - millennial generation; interface; smartphone; usability.

Abstrak - Perkembangan teknologi smartphone di Indonesia saat ini tentunya tidak terlepas dari pengaruh gaya hidup generasi millennial. Dimana kelompok konsumen muda ini dikenal sebagai generasi yang paling terkoneksi secara sosial dan sangat mendominasi jumlah pengguna smartphone di Indonesia dalam tiga tahun terakhir. Salah satu perkembangan teknologi tersebut terdapat pada interface produk smartphone. Semakin baik tingkat usabilitas suatu interface, tentunya semakin memudahkan penggunanya dan menimbulkan loyalitas terhadap produk tersebut. Sehingga penelitian ini dilakukan untuk mengetahui perbandingan tingkat usabilitas interface dua produk smartphone terlaris di Indonesia, yakni Iphone dan Samsung. Penelitian dilakukan dengan metode observasi langsung terhadap responden yang mewakili populasi generasi millennial di Kabupaten Ciamis. Responden akan menyelesaikan 10 tugas sebanyak empat kali percobaan pada masingmasing interface. Hasil penelitian ini menunjukkan bahwa interface Samsung lebih unggul pada dimensi efficiency, error, dan memorability. Sedangkan interface Iphone lebih unggul pada dimensi learnability dan satisfaction. Disamping itu, terdapat pula rekomendasi usulan perbaikan yang dapat dilakukan oleh para pengembang untuk penyempurnaan interface produk smartphone.

Kata kunci-generasi millennial; interface; smartphone; usabilitas.

\section{PENDAHULUAN}

Konsumen millennial atau juga dikenal dengan sebutan Generasi Y, merupakan konsumen berusia 18-31 tahun [2] dengan kecenderungan menginginkan segala sesuatu yang bersifat instan [1]. Sehingga berpotensi untuk menjadi target pasar produk-produk berteknologi tinggi. Konsumen ini juga memiliki karakteristik unik, yakni daya beli yang tinggi dan cenderung berorientasi terhadap merk suatu produk [3]. Disamping itu, konsumen millennial juga dikenal generasi yang paling terkoneksi secara sosial.
Penggunaan internet sangat berpengaruh pada generasi ini, dimana semua batasan informasi terbuka lebih luas untuk diakses [4].

Meningkatnya aktivitas komunikasi dan penggunaan internet untuk berbagai kebutuhan, menuntut masing-masing individu untuk memiliki sebuah alat komunikasi berupa smartphone. Terlebih individu yang berada pada usia produktif pada hampir semua generasi, termasuk juga generasi millennial [5]. Pengguna smartphone di Indonesia meningkat hingga $81,8 \%$ sejak tiga tahun terakhir ini, dimana penggunanya didominasi oleh para konsumen millennial [6]. 
Bahkan dalam perharinya, penggunaan smartphone pada konsumen generasi ini dapat menghabiskan hingga 18 jam [6]. Oleh karena itu, perkembangan teknologi produk yang masuk ke Indonesia pun perlu mengikuti gaya hidup generasi ini.

Salah satu perkembangan teknologi tersebut terdapat pada interface produk smartphone. Dimana interface merupakan bentuk tampilan grafis yang berhubungan langsung dengan pengguna smartphone [7]. Beragam interface yang ditawarkan produsen smartphone saat ini, memiliki tingkat usabilitas yang berbeda-beda. Semakin baik tingkat usabilitas suatu interface, tentunya semakin memudahkan penggunanya dan menimbulkan loyalitas terhadap produk tersebut [8].

Di Indonesia, dua merk smartphone terlaris dalam kuartal dua tahun ini adalah Iphone dan Samsung dengan berbagai tipe [6][9]. Namun hingga saat ini, analisis tingkat usabilitas interface dua produk tersebut belum pernah diteliti lebih lanjut, khususnya pada penggunanya yang paling mendominasi, yakni konsumen millennial. Analisis usabilitas dapat diukur pada interface produk smartphone diantaranya tingkat kemudahan digunakan (learnability), efisiensi (efficiency), kemudahan untuk diingat oleh pengguna (memorability), kesalahan (error), serta kepuasan (satifaction) yang dirasakan oleh pengguna [10][11].

Dalam pengukuran satisfaction, dapat menggunakan berbagai metode diantaranya adalah metode System Usability Scale atau SUS. Rata-rata nilai SUS yang berada di bawah 68 menunjukkan bahwa, pengguna memiliki pengalaman tidak menyenangkan saat menggunakan obyek yang diukur, sehingga dinyatakan belum puas menggunakan obyek tersebut. Sedangkan nilai di atas 68 menunjukkan bahwa pengguna telah puas dalam menggunakan obyek tersebut. Namun nilai SUS yang telah mencapai 82, maka menunjukkan bahwa pengguna tersebut sangat puas hingga bersedia untuk merekomendasikan obyek tersebut kepada orang lain untuk menggunakannya (Brooke, 2013).

Dengan demikian, penelitian ini dilakukan untuk mengetahui perbandingan tingkat usabilitas dua produk smartphone terlaris di Indonesia, yakni Iphone dan Samsung berdasarkan penilaian konsumen millennial. Hasil akhir dari penelitian ini berupa rekomendasi perbaikan yang dapat dilakukan untuk meningkatkan kepuasan pengguna dalam menggunakan dua produk smartphone tersebut, maupun masukan bagi para pengembang smartphone interface lainnya.

\section{Metodologi Penelitian}

Obyek penelitian ini adalah interface pada produk Iphone seri 5S dan Samsung seri S7. Sedangkan yang menjadi subyek penelitian adalah responden pemula, atau responden yang belum pernah menggunakan smartphone tersebut dengan batasan usia 18-35 tahun, dan berdomisili di Kabupaten Ciamis.

Penelitian diawali dengan melakukan uji pilot study untuk memastikan pengambilan data yang dilakukan telah sesuai dengan metode pengukuran usabilitas. Kemudian dilanjutkan ke observasi pertama untuk mengukur dimensi learnability, efficiency, dan error. Adapun dimensi memorability akan diukur pada obervasi kedua yang dilaksanakan 1 minggu setelah obvervasi pertama. Selain itu, digunakanan pula metode System Usability Scale atau SUS untuk mengukur dimensi satisfaction.

Penelitian dilakukan pada 10 tugas yang biasa digunakan pada smartphone sebanyak empat kali percobaan. Tugas diurutkan dari yang paling mudah hingga yang paling sulit. Urutan tugas tersebut adalah membuka kunci tanpa sandi, mengaktifkan penggunaan data seluler untuk mengakses internet, melakukan cuplikan layar (screenshot) pada tampilan tertentu, mengambil gambar dengan menggunakan kamera depan, membuka galeri penyimpanan gambar, mengirim gambar melalui perangkat bluetooth pada Samsung dan airdrop pada Iphone, menyimpan nomor kontak beserta namanya, mengirim pesan singkat, mengaktifkan WiFi, dan mengunci perangkat tanpa sandi.

Setelah tahap observasi, maka penelitian dapat dilanjutkan ke pengolahan data, untuk kemudian membandingkan tingkat usabilitas kedua interface dan mengevaluasi kekurangan masing-masing interface. Berdasarkan analisis dari tahap sebelumnya, kemudian disusun suatu rekomendasi perbaikan yang dapat dilakukan oleh pihak pengembang interface kedua merk smartphone tersebut, maupun untuk merk kompetitor lainnya.

Adapun diagram alir penelitian ini disajikan pada Gambar 1.

\section{HASIL PENELITIAN}

Dari penelitian yang telah dilakukan didapatkan tingkat usabilitas masing-masing interface yang dibandingkan berdasarkan masingmasing dimensi. 


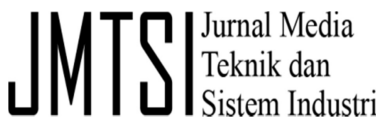

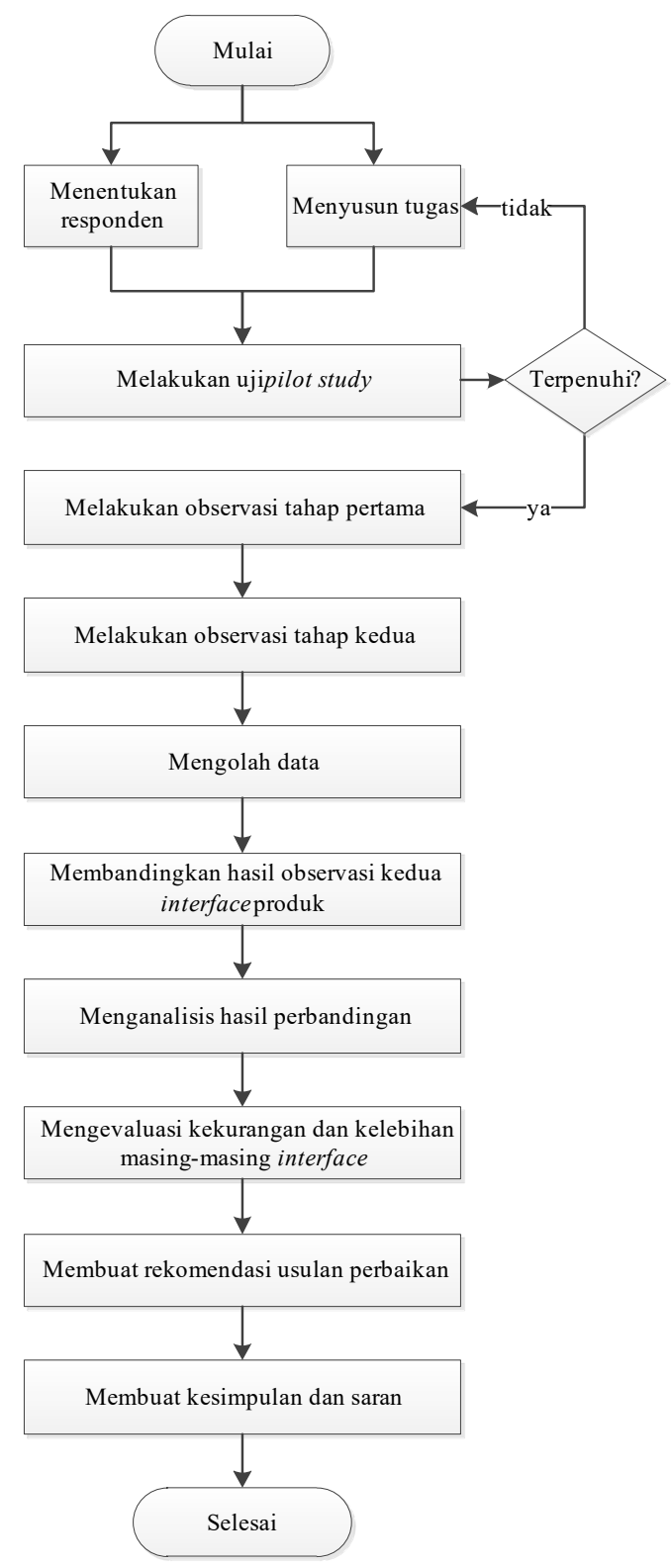

Gambar 1. Diagram Alir Penelitian

\section{A. Dimensi Learnability}

Learnability adalah proses belajar seseorang terhadap sistem dari pemula menjadi expert. Sistem yang baik mempunyai nilai learnability yang rendah, yakni menandakan mudah digunakan sehingga pengguna dapat menyelesaikan tugasnya dengan cepat. Hasil pengukuran learnability dapat dilihat pada Gambar 2 dan 3.

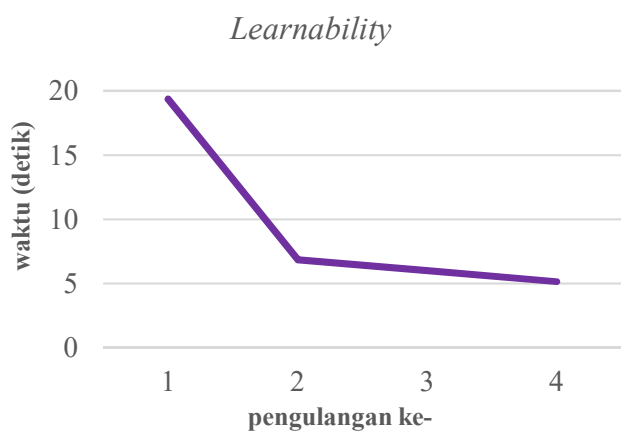

Gambar 2. Grafik Learnability Iphone

Learnability

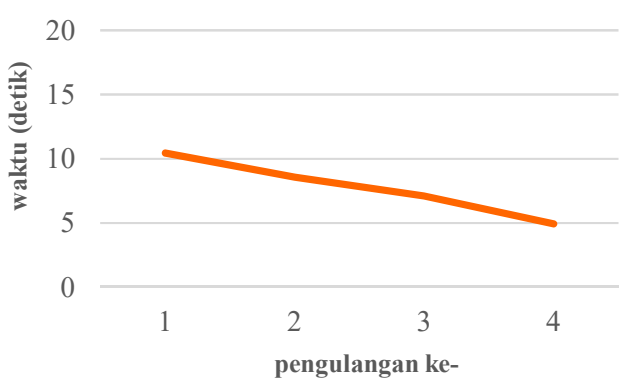

Gambar 3. Grafik Learnability Samsung

\section{B. Dimensi Efficiency}

Dimensi efficiency dalam penelitian ini mengukur tingkat kecepatan responden dalam menyelesaikan tugas setelah mereka mempelajari cara penggunaan interface tersebut. Data yang diambil berupa waktu rata-rata responden dalam menyelesaikan 10 tugas setelah pengulangan yang keempat kalinya. Adapun total waktu penyelesesaian 10 tugas tersebut pada interface Iphone mencapai 51,33 detik. Sedangkan pada interface Samsung mencapai 49,21 detik.

Perbandingan tingkat efficiency pada interface Iphone dan Samsung yang dilakukan responden disajikan pada Gambar 4 dan 5 berikut.

\section{Efficiency}

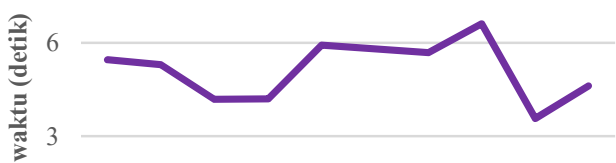

0

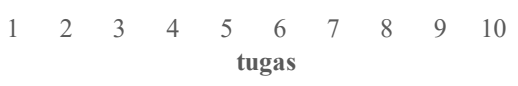

Gambar 4. Grafik Efficiency Iphone 


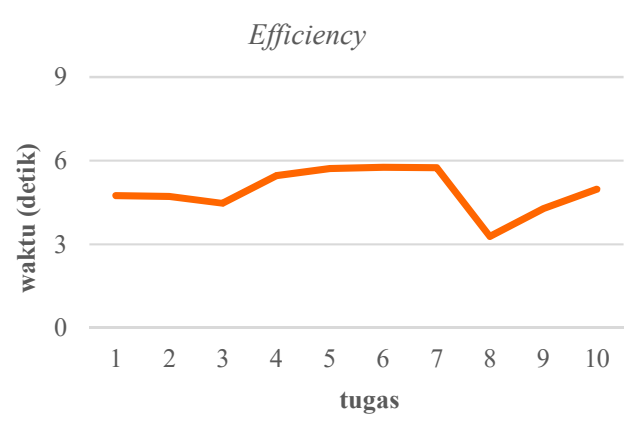

Gambar 5. Grafik Efficiency Samsung

\section{Dimensi Error}

Dimensi error dalam penelitian ini dinilai untuk mengetahui seberapa banyak dan serius kesalahan pada pengerjaan tugas, serta seberapa lama responden dapat memperbaiki kesalahan tersebut hingga dapat menyelesaikan tugas. Data yang diambil adalah berupa jumlah kesalahan yang dibuat pada tiap-tiap tugas. Perbandingan total kesalahan yang dilakukan responden pada masing-masing interface dapat dilihat pada Gambar 6 berikut.

\section{Perbandingan Error}

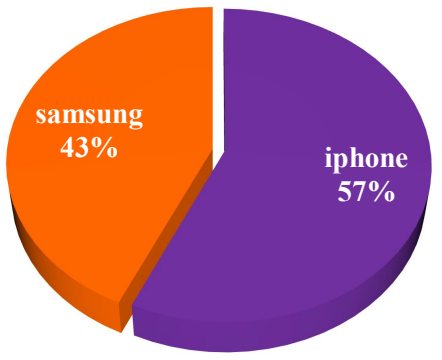

Gambar 4. Perbandingan Error

Adapun jumlah error yang paling banyak terjadi pada tiap tugas secara berturut-turut disajikan dengan Diagram Pareto pada Gambar 7 dan 8 berikut.

\section{Dimensi Memorability}

Dimensi memorability pada penelitian ini menunjukkan kemampuan interface pada masingmasing produk untuk dapat diingat oleh penggunanya, dimana interface tersebut digunakan lagi setelah sekian periode tidak digunakan tanpa harus mempelajari penggunaan interface kembali. Rangkaian tugas yang dilakukan merupakan tugas yang sama pada tahap pengukuran learnability. Hasil pengukuran memorability pada interface Iphone dan Samsung disajikan melalui grafik pada Gambar 9 dan 10 berikut.

Jumlah Kesalahan Tiap Tugas

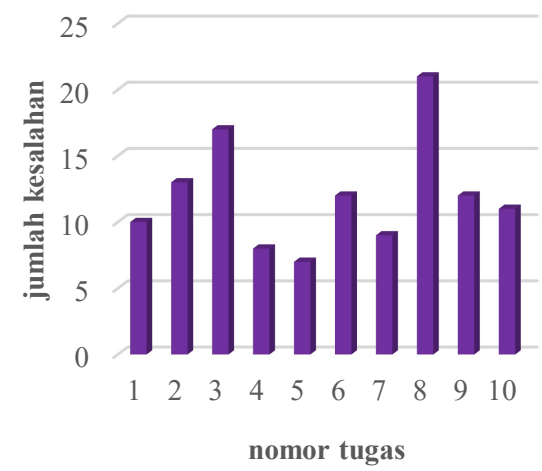

Gambar 7. Jumlah Error Iphone

Jumlah Kesalahan Tiap Tugas

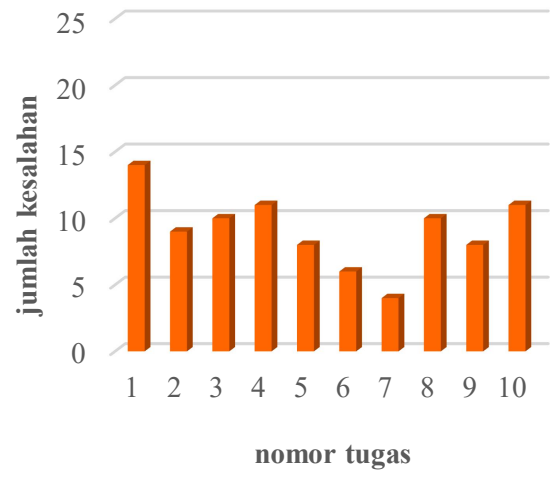

Gambar 8. Jumlah Error Samsung

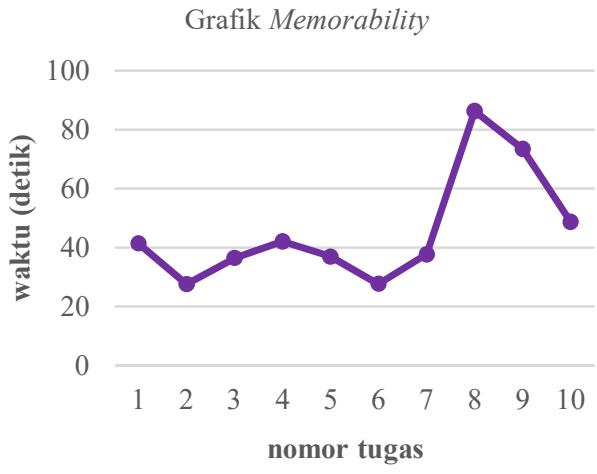

Gambar 9. Perbandingan Memorability Iphone 


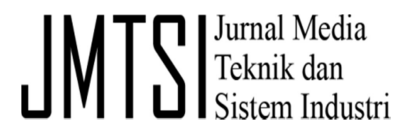

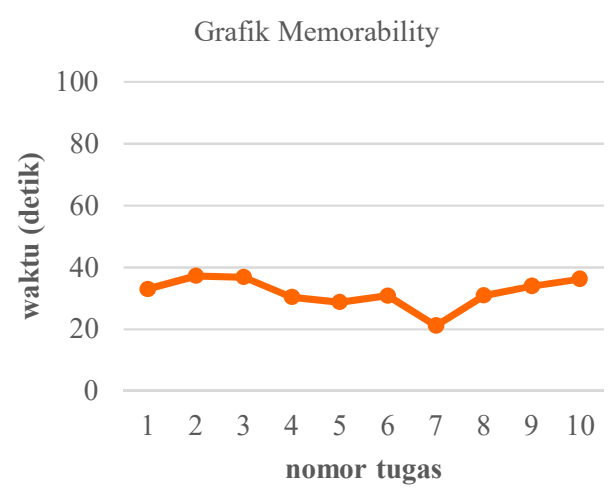

Gambar 10. Perbandingan Memorability Samsung

\section{E. Dimensi Satisfaction}

Satisfaction adalah pengalaman yang didapatkan oleh pengguna setelah menggunakan obyek penelitian, sehingga pengukuran ini cenderung bersifat subyektif. Walaupun demikian, pengukuran ini banyak memberi masukan kekurangan maupun kelebihan pada obyek yang diukur. Sehingga dapat menjadi masukan sebagai rekomendasi perbaikan obyek penenelitian.

Pengukuran satisfaction dapat dilakukan dengan berbagai metode, salah satunya adalah metode System Usability Scale atau SUS dengan media kuesioner. Pada penelitian ini, pengukuran kepuasan pengguna dalam menggunakan interface masing-masing smartphone diukur dengan kuesioner SUS yang telah diuji validitas dan reliabilitasnya.

Nilai SUS dari responden pemula yang menggunakan interface Iphone adalah sebesar 46,7. Sedangkan nilai SUS dari responden pemula yang menggunakan interface Iphone adalah sebesar 54,2.

\section{IV.PEMBAHASAN}

Berdasarkan pengolahan data dan hasil yang didapatkan dari pengukuran usabilitas kedua interface, berikut pembahasan untuk masingmasing dimensi:

\section{A. Dimensi Learnability}

Hasil pengukuran dimensi learnability pada Gambar 2 menunjukkan bahwa interface pada smartphone Iphone lebih cepat mencapai titik learnabilitas dibanding interface pada produk Samsung. Hal tersebut dapat dilihat berdasarkan pada pengulangan keberapa waktu penyelesaian tugas mulai konstan pada rata-rata waktu tertentu.
Pada Gambar 2, grafik learnability menunjukkan bahwa rata-rata waktu penyelesaian tugas pada interface Iphone mulai konstan di pengulangan kedua. Rata-rata waktu penyelesaian tugas pada pengulangan ketiga dan keempat terlihat tidak jauh berbeda dengan rata-rata waktu pada pengulangan kedua, yakni pada detik ke 5-6. Di sisi lain, rata-rata waktu penyelesaian interface Samsung terus mengalami penurunan sejak percobaan pertama. Namun belum juga mencapai titik konstan hingga pengulangan keempat, walaupun rata-rata waktu penyelesaiannya lebih cepat dibanding rata-rata waktu penyelesaian tugas pada interface Iphone.

Dengan demikian, tingkat learnability interface Iphone dapat disimpulkan lebih baik dibanding interface Samsung.

\section{B. Dimensi Efficiency}

Hasil pengukuran dimensi efficiency pada Gambar 3 menunjukkan bahwa interface Iphone maupun Samsung hampir baiknya. Rata-rata waktu penyelesaian masing-masing tugas pada pengulangan kedua sampai keempat hanya berbeda sepersekian detik. Namun hanya pada tugas 4 dan 8 yang perbedaannya cukup signifikan.

Tugas keempat adalah mengambil gambar dengan menggunakan kamera depan, dimana responden membutuhkan rata-rata waktu yang lebih lama saat menggunakan interface Samsung dibanding Iphone. Sedangkan tugas 8 adalah mengirim pesan singkat, dimana responden membutuhkan waktu yang jauh lebih lama saat menggunakan interface Iphone dibanding Samsung.

Dengan demikian, dapat disimpulkan secara keseluruhan bahwa kedua interface hampir sama baiknya pada dimensi efficiency.

\section{Dimensi Error}

Hasil pengukuran dimensi error pada Gambar 4 menunjukkan bahwa kesalahan lebih banyak terjadi pada saat responden menggunakan interface Iphone dibanding Samsung. Walaupun perbedaan tersebut tidak begitu jauh bedanya, yakni sekitar $14 \%$.

Disamping itu, dapat diketahui juga kesalahan terbanyak yang dilakukan responden pada masing-masing tugas. Pada interface Iphone, responden paling banyak melakukan kesalahan pada tugas 8 dan 3 . Dimana tugas ke 8 adalah mengirimkan pesan singkat, sedangkan tugas ke 3 
adalah melakukan screenshoot pada tampilan tertentu. Sedangkan pada interface Samsung, responden paling banyak melakukan kesalahan pada tugas 1 yakni membuka kunci tanpa sandi.

Dengan demikian, dapat disimpulkan secara keseluruhan bahwa interface Samsung lebih baik dibanding interface Iphone pada dimensi error. Dimana interface Samsung dapat meminimalisir kesalahan dibanding interface Iphone.

\section{Dimensi Memorability}

Hasil pengukuran dimensi memorability pada Gambar 6 menunjukkan bahwa interface Iphone dan interface Samsung hampir sama baiknya. Rata-rata waktu penyelesaian tugas setelah 1 minggu dari percobaan pertama pada masingmasing interface tidak jauh berbeda, khususnya pada tugas 1 hingga ke 7 . Namun pada tugas 8 hingga 10, responden menghabiskan lebih banyak waktu untuk mengingat kembali cara penyelesaian tugas pada interface Iphone. Tugas 8 hingga 10 berturut-turut adalah mengirim pesan singkat, mengaktifkan WiFi, dan mengunci perangkat tanpa sandi.

Dengan demikian, dapat disimpulkan secara keseluruhan bahwa interface Samsung lebih baik dibanding interface Iphone pada dimensi memorability.

\section{E. Dimensi Satisfaction}

Hasil pengukuran dimensi satisfaction menggunakan kuesioner SUS menunjukkan bahwa responden belum merasa puas dalam menggunakan kedua interface tersebut. Dimana nilai kuesioner SUS baik pada interface Iphone maupun interace Samsung masih berada di bawah 68.

Walaupun demikian, responden mendapat pengalaman yang lebih menyenangkan saat menggunakan interface Iphone dengan skor mencapai 54,2 dibanding saat menggunakan interface Samsung yang hanya mencapai skor 46,7 .

\section{F. Perbandingan Usability Keseluruhan}

Berdasarkan hasil perbandingan kelima dimensi usabilitas pada kedua interface, maka dapat disimpulkan bahwa interface Iphone memiliki nilai yang lebih baik pada dimensi learnability dan satisfaction. Sedangkan interface Samsung memiliki nilai yang lebih baik pada dimensi efficiency, error, dan memorability.

Dengan demikian, interface Iphone dinilai lebih mudah untuk dipelajari, serta memberikan kesan menyenangkan dan memberikan kepuasan dalam penggunaannya. Sedangkan interface Samsung dinilai lebih efisien, dapat meminimalisir kesalahan, dan lebih mudah diingat dalam penggunaannya.

\section{G. Kekurangan dan Kelebihan Interface}

Interface pada masing-masing smartphone tentunya memiliki kelebihan dan kekurangan. Berdasarkan hasil observasi ke seluruh responden, analisis kelebihan dan kekurangan pada masingmasing interface dapat dilihat pada Tabel 1 berikut.

TABEL I

KEKURANGAN INTERFACE

\begin{tabular}{|c|c|c|}
\hline Interface & Iphone & Samsung \\
\hline $\begin{array}{l}\text { Kamera } \\
\text { depan }\end{array}$ & - & $\begin{array}{l}\text { Lebih sulit } \\
\text { digunakan }\end{array}$ \\
\hline $\begin{array}{c}\text { Pesan } \\
\text { singkat }\end{array}$ & $\begin{array}{c}\text { Responden } \\
\text { butuh waktu } \\
\text { lama untuk } \\
\text { mengirim SMS }\end{array}$ & - \\
\hline $\begin{array}{l}\text { Screen } \\
\text { shoot }\end{array}$ & $\begin{array}{c}\text { Responden } \\
\text { banyak } \\
\text { melakukan } \\
\text { kesalahan }\end{array}$ & - \\
\hline $\begin{array}{l}\text { Buka kunci } \\
\text { tanpa sandi }\end{array}$ & - & $\begin{array}{c}\text { Responden } \\
\text { banyak } \\
\text { melakukan } \\
\text { kesalahan }\end{array}$ \\
\hline $\begin{array}{c}\text { Mengatifkan } \\
\qquad W F i\end{array}$ & $\begin{array}{c}\text { Responden sulit } \\
\text { untuk mengingat } \\
\text { cara } \\
\text { mengaktifkan } \\
\text { WiFi }\end{array}$ & - \\
\hline
\end{tabular}

\section{H. Rekomendasi Usulan}

Berdasarkan hasil analisis dimensi usabilitas dan kekurangan dari masing-masing interface, maka dapat diusulkan beberapa rekomendasi berikut:

1) Kamera depan pada Interface Samsung: Sejak tahun 2013, "selfie" merupakan aktivitas yang paling sering dilakukan oleh pengguna smartphone di waktu luang mereka, ataupun untuk merekam momen yang berkesan [13]. Oleh karena itu, interface kamera depan pada smartphone memerlukan usabilitas yang memadai 


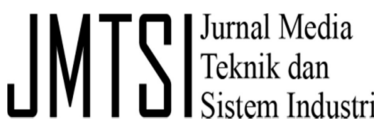

guna memenuhi kebutuhan penggunanya. Pada saat observasi, responden merasa kesulitan dalam menggunakan kamera depan Samsung, dimana responden memakan waktu yang cukup lama saat mencari ikon untuk mengganti kamera belakang ke kamera depan.

2) Membuka kunci tanpa sandi pada Interface Samsung: Fitur pengunci diperlukan dengan tujuan untuk keamanan smartphone. Fitur ini juga dapat dilengkapi dengan menggunakan sandi. Pada smartphone Samsung, untuk membuka kunci tanpa sandi memerlukan sentuhan jari pengguna pada layar. Dimana responden banyak melakukan kesalahan saat melakukan tugas ini. Interface unlock pada Samsung dinilai masih belum memberikan informasi yang cukup bagaimana teknis membuka kunci tersebut, terutama juga penggunanya dalam keadaan terburu-buru untuk menggunakan smartphonenya.

3) Pesan singkat pada Iphone: pesan singkat atau SMS saat ini memang sudah jarang digunakan, dimana pengguna pada umumnya lebih memilih menggunakan aplikasi chat untuk berkomunikasi dengan pengguna lainnya. Oleh karena itu, fitur pesan singkat tidak begitu familiar dimata pengguna. Begitu pun halnya yang terjadi pada responden saat menyelesaikan tugas mengirim pesan singkat. Responden membutuhkan waktu yang cukup lama saat mencari ikon pesan singkat dan mencari kolom untuk mengetik pesan.

Dengan demikian, perlu dilakukan penyempurnaan interface pada Iphone, agar pengguna lebih familiar saat akan mengirimkan pesan singkat.

4) Screenshoot pada Interface Iphone: Fitur cuplikan layar diperlukan untuk berbagai kebutuhan penyimpanan informasi dari layar smartphone. Dimana fitur ini terkadang diperlukan pada waktu yang singkat, sehingga pengguna memerlukan jalan pintas untuk mengoperasikannya. Terdapat dua cara untuk melakukan cuplikan layar pada interface Iphone. Namun kedua jalan pintas itupun dinilai masih belum membantu pengguna untuk melakukan cuplikan layar di saat-saat tertentu. Responden cenderung melakukan kesalahan saat melakukan tugas ini. Oleh karena itu, diperlukan penyempurnaan interface yang lebih informatif untuk memudahkan pengguna dalam melakukan cuplikan layar di saat-saat tertentu.

5) WiFi activation pada interface Iphone: Meningkatnya fasilitas $W i F i$ di berbagai area umum tentunya sangat membantu para pengguna smartphone untuk mengakses internet. Namun smartphone memiliki keterbatasan baterai yang akan lebih cepat habis saat mengaktifkan WiFi. Sehingga pengguna harus mematikan fitur tersebut sewaktu-waktu untuk menghemat penggunaan baterai smartphone mereka. Pada interface Iphone, lokasi ikon untuk WiFi activation tersebut dinilai cukup sulit untuk diingat kembali jika sudah tidak digunakan dalam waktu yang lama. Sehingga responden banyak menghabiskan waktu hanya untuk meaktifkan maupun mematikan fitur WiFi pada smartphone mereka. Oleh karena itu, diperlukan interface yang lebih mudah diingat untuk memudahkan pengguna dalam melakukan tugas tersebut.

\section{KESIMPULAN}

Hal-hal yang dapat disimpulkan dari hasil penelitian ini diantaranya adalah tingkat usabilitas interface yang berdasarkan penilaian generasi Millennial sudah cukup memadai. Namun diperlukan pula beberapa penyempurnaan untuk memudahkan pengguna, khususnya pada fitur yang paling sering digunakan oleh para konsumen muda. Rekomendasi perbaikan yang merupakan hasil akhir dari penelitian ini, telah dianalisis dan dapat dijadikan bahan pertimbangan para pengembang interface untuk penyempurnaan produk mereka.

\section{UCAPAN TERIMA KASIH}

Penulis mengucapkan banyak terimakasih kepada pihak-pihak yang telah turut berpartisipasi terutama kepada:

1. Mahasiswa/i Teknik Industri Universitas Galuh angkatan 2014 yang telah menjadi responden dalam penelitian ini.

\section{REFERENSI}

[1] E. D. Septiari, dan N. N. Sari, "Persepsi Konsumen Milenial Terhadap Kualitas Layanan Pasar Tradisional", MODUS Journals, vol. 30, no. 1, pp. 116, 2018.

[2] R. Fry, "A Rising Share of Young Adults Live in Their Parents' Home", Pew Research Center, [Online]. Available: https://www.researchgate.net/publication/ 321171445/download

[3] I. Luntungan, et al, "Strategi Pengelolaan Generasi Y di Industri Perbankan", Jurnal Manajemen Teknologi, vol. 13, no. 2, pp. 219-240, Agustus 2014.

[4] G. Browning dan D. Worman, "Gen Up: How The Four Generations Work", Chartered Institute of Personnel and Development, 2009, [Online]. Available: https://www.criticaleye.com/inspiring/insightsservfile.cfm? $\mathrm{id}=2183$

[5] T. Angela dan N. Effendy, "Faktor-Faktor Brand Loyalty Smartphone pada Generasi Y", Jurnal Experientia, vol. 3, no. 1, pp. 79-91, Juli 2015. 
[6] ACH, "Penggunaan "Smartphone" di Genggaman Generasi Milenial", Kompas, Mei 05, 2018. [Online]. Available https://kompas.id/baca/adv_post/penggunaansmartphone-di-genggaman-generasi-millenial/

[7] A. G. Akeda, "7 User Interface Terbaik Smartphone", Tribunstyle.com, Sept 06, 2018. [Online]. Available: http://style.tribunnews.com/2017/01/16/ini-7-userinterface-terbaik? $=4$

[8] R. F. Budi, "Pengaruh Kualitas Web Terhadap Tingkat Kepuasan Penggunaan Google Scholar", Jurnal UNAIR, 2010.

[9] JCND, "5 Merek Smartphone Paling Laris di Dunia", idntimes, September 05, 2018. [Online]. Available: https://www.idntimes.com/tech/gadget/jcnd/daftarmerek-smartphone-paling-laris-di-dunia-c1c2/full.

[10] J. Nielsen, Usability Engineering, San Diego: Academic Press, 1993.

[11] H. Mastrisiswadi, et al, "Analisis Perbandingan Tingkat Usabilitas Pada Webmail Services (Gmail \& Hotmail)", Proceeding of Seminar Nasional Teknik Industri Universitas Gadjah Mada, vol. 1, 2016.

[12] G. W. L. Soerjoatmodjo, "I Selfie Therefore I Exist: A Preliminary Qualitative Research on Selfie as Part of Identity Formation in Adolescents", HUMANIORA, vol. 7, no. 2, pp. 139-148, April 2016. 